\title{
Exposure of $\beta_{L}$-crystallin to oxidizing free radicals enhances its susceptibility to transglutaminase activity
}

\author{
Milfred SECCIA,* Olga BROSSA, ${ }^{*}$ Enrico GRAVELA, ${ }^{*}$ Trevor F. SLATER $\dagger$ and Kevin H. CHEESEMAN $\dagger$ \\ *Dipartimento di Scienze Cliniche e Biologiche Università di Torino, Torino, Italy, and †Department of Biology and \\ Biochemistry, Brunel University, Uxbridge UB8 3PH, U.K.
}

\begin{abstract}
1. The effects of free radicals on the capacity of $\beta_{\mathrm{L}}$-crystallin to act as a substrate for the enzyme transglutaminase were investigated. 2. $\beta_{\mathrm{L}}$-Crystallin was exposed to defined radical species that were generated radiolytically, and transglutaminase activity, using the modified protein as substrate, was subsequently measured by monitoring the incorporation of $\left[{ }^{14} \mathrm{C}\right]$ putrescine. 3. Exposure of $\beta_{\mathrm{L}}$-crystallin to hydroxyl radicals, thymine peroxyl radicals and acetone peroxyl radicals at concentrations of up to $135 \mu \mathrm{M}$ increased the capacity of the protein to incorporate putrescine. With higher concentrations of these radicals this capacity of $\beta_{\mathrm{L}}$-crystallin to act as a transglutaminase substrate declined to control levels or lower. 4. Superoxide radicals were inactive in this regard; hydroperoxyl radicals were active only at high concentrations. 5 . It has previously been suggested that changes in the crystallins that occur during aging and with cataract may be due to oxidative reactions and to transglutaminase activity. This study suggests that these phenomena may be considered together rather than separately.
\end{abstract}

\section{INTRODUCTION}

The crystallins, the major structural proteins of the lens, have proved to be very useful in studying post-translational alterations of protein structures in relation to the phenomena of cell aging. The vertebrate lens contains some of the body's oldest proteins, some of them having been synthesized before birth. Therefore, in a long-lived vertebrate such as man, the lens proteins have a very long time to accumulate age-related modifications. There are several well-documented changes which occur in the human lens: conversion of the protein from a soluble into an insoluble form, increase in disulphide and a decrease in thiol groups, development of pigmentation, specific limited cleavages of the polypeptide chains and decreased antioxidant protection, to name but a few (Zigler \& Goosey, 1981; Taylor \& Davies, 1987). The changes to the proteins of the lens are complex and not fully characterized, and they probably involve several mechanisms acting in concert (see Harding, 1981). These changes result in a high level of covalently cross-linked proteins that bring about a loss of transparency and a characteristic opacity of the lens, resulting in reduction of visual function and culminating in senile cataract (Kramps et al., 1976). The ocular lens is exposed in vivo to a high level of oxidative stress, both from oxidants present in the fluids surrounding the lens and from oxidants generated within the lens itself, particularly by photochemical reactions (Spector, 1985). Thus the thiol groups of the human lens proteins may undergo oxidation to form disulphide bonds that cross-link protein molecules (Harding, 1972; Truscott \& Augustein, 1977a, $b$; Anderson \& Spector, 1978). Aged and cataractous lens contains also polypeptides that are resistant to disaggregation by urea and SDS (Kramps et al., 1978). This suggests that these aggregates have formed from lens proteins by a process of cross-linking involving covalent bonds other than disulphide bonds. The isolation of $\gamma$-glutamyl- $\epsilon$-lysine isopeptides from polymers characteristically present only in specimens of human cataract, and the finding of transglutaminase (TGase) activity in the lens suggest a possible role of this enzyme in the terminal differ- entiation of lens fibre cells and also in the process of cataractogenesis (Lorand et al., 1981). TGase activity is dependent on a relatively high $\mathrm{Ca}^{2+}$ concentration, but, in the lens, the $\mathrm{Ca}^{2+}$ concentration varies between 0.5 and $2 \mathrm{mM}$ (Clark et al., 1980, and references cited therein), this being sufficient to activate the enzyme to an appreciable extent. Furthermore, $\mathrm{Ca}^{2+}$ levels increase in aged and cataractous lenses (Krause, 1934; Duncan \& Bushell, 1975), and it has been demonstrated that $\mathrm{Ca}^{2+}$ is capable of inducing aggregates of normal $\alpha$-crystallin in the human lens in vitro (Jedziniak et al., 1972). A second type of control can occur by an increased substrate susceptibility to TGase possibly dependent on conformational changes induced by post-translational modifications. Such conformational changes might be caused by oxidative stress; reactive free radicals may increase the accessibility of amine acceptor sites, making crystallins more susceptible to TGase activity. Preliminary studies indicate that oxidant injury is able to increase the susceptibility of $\beta_{\mathrm{L}}$-crystallin to TGase (Brossa et al., 1990). We have used $\gamma$ irradiation to generate specific oxygen free radicals and investigated the effect of these radicals on the capacity of crystallin to act as a substrate for exogenous TGase activity. Our results indicate that oxidative stress may contribute to the cross-linking of lens crystallins not only directly, but also indirectly, by increasing the susceptibility of the protein to TGase activity.

\section{MATERIALS AND METHODS}

Bovine lens $\beta_{\mathrm{L}}$-crystallin and guinea-pig liver transglutaminase were purchased from Sigma. $\left[1,4-{ }^{14} \mathrm{C}\right]$ Putrescine was purchased from Amersham International. Protosol solubilizer and Econofluor scintillation fluid were obtained from New England Nuclear.

\section{Exposure of crystallin to free radicals}

$\beta_{\mathrm{L}}$-Crystallin, in double-distilled and deionized water, at a concentration of $1 \mathrm{mg} / \mathrm{ml}$, was exposed to various concentrations of oxygen-centred radicals using the Brunel University ${ }^{60} \mathrm{Co}$

Abbreviations used: TGase, transglutaminase; $\mathrm{e}^{-}{ }_{\text {aq. }}$, solvated electron; $\mathrm{OH}^{*}$, hydroxyl radical; $\mathrm{H}^{*}$, hydrogen atom; $\mathrm{O}_{2}^{-{ }^{-}}$, superoxide radical; $\mathrm{HO}_{2}{ }^{\circ}$, hydroperoxyl radical; $\mathrm{Nbs}_{2}, 5,5^{\prime}$-dithiobis-(2-nitrobenzoic acid).

$\ddagger$ To whom correspondence should be addressed. 
source at a dose rate of $7.8 \mathrm{~Gy} / \mathrm{min}$ as measured by Fricke \& Hart (1966) dosimetry, up to a total dose of $1000 \mathrm{~Gy}$. By using techniques defined previously (Willson, 1978), specific radical formation was achieved by careful design of the irradiation system. Briefly, in the radiolysis of water, the main primary species formed are $\mathrm{OH}^{\circ}, \mathrm{e}^{-}$aq. and $\mathrm{H}^{\circ}$. Radiolytic yields are expressed as $G$ values ( $\mu \mathrm{M}$-radicals/10 Gy): $G_{\mathrm{OH}^{\cdot}}=2.7$; $G_{\mathrm{e}^{-}}=2.7$, whereas $G_{\mathrm{H}^{\cdot}}=0.55$. If the system is saturated with $\mathrm{N}_{2} \mathrm{O}$, the solvated electron reacts quantitatively such that $90 \%$ of the free radicals produced are $\mathrm{OH}^{*}$ :

$$
\mathrm{e}^{-}{ }_{\text {aq. }}+\mathrm{N}_{2} \mathrm{O} \rightarrow \mathrm{OH}^{\cdot}+\mathrm{N}_{2}+\mathrm{OH}^{-}
$$

If $\mathrm{O}_{2}$ is present in the system $\left(\mathrm{N}_{2} \mathrm{O} / \mathrm{O}_{2}, 4: 1, \mathrm{v} / \mathrm{v}\right)$, it can react with carbon-centred substrate radicals generated by $\mathrm{OH}^{\cdot}$ radicals, converting them into the corresponding substrate-peroxyl radicals.

Superoxide radicals $\left(\mathrm{O}_{2}^{-\cdot}\right)$ can be generated in this system if sodium formate $(0.01 \mathrm{M})$ is included. Adjustment of this system to $\mathrm{pH} 4$ enables the conversion of most of the $\mathrm{O}_{2}^{--}$to hydroperoxyl radical $\left(\mathrm{HO}_{2}^{\circ}\right)$. In order to generate examples of organic peroxyl radicals, acetone or thymine is added to the solution (saturated with $\mathrm{N}_{2} \mathrm{O} / \mathrm{O}_{2}, 4: 1, \mathrm{v} / \mathrm{v}$ ), where $\mathrm{OH}^{\cdot}$ radicals react with them by hydrogen abstraction. Thus, for acetone:

$$
\begin{gathered}
\mathrm{OH}^{\bullet}+\mathrm{CH}_{3} \mathrm{COCH}_{3} \rightarrow \mathrm{H}_{2} \mathrm{O}+{ }^{\cdot} \mathrm{CH}_{2} \mathrm{COCH}_{3} \\
\mathrm{O}_{2}+{ }^{\cdot} \mathrm{CH}_{2} \mathrm{COCH}_{3} \rightarrow{ }^{\cdot} \mathrm{O}_{2} \mathrm{CH}_{2} \mathrm{COCH}_{3}
\end{gathered}
$$

At the acetone concentration used ( $1 \mathrm{~mm})$ the system consists primarily of acetonyl peroxyl radicals $(G=5.2$; Zegota et al., 1986).

In a solution containing thymine $(1 \mathrm{mM})$ the $\mathrm{OH}^{\bullet}$ radicals will react with the 5,6 double bond, giving the hydroxyl-free-radical adduct of thymine $\left[\mathrm{T}\left(\mathrm{OH}^{\circ}\right)\right]$ that, in the presence of $\mathrm{O}_{2}$, will be transformed to the corresponding peroxyl radical:

$$
\begin{gathered}
\mathrm{T}+\mathrm{OH}^{\bullet} \rightarrow \mathrm{T}\left(\mathrm{OH}^{*}\right) \\
\mathrm{T}\left(\mathrm{OH}^{\bullet}\right)+\mathrm{O}_{2} \rightarrow \mathrm{T}(\mathrm{OH}) \mathrm{O}_{2} \cdot
\end{gathered}
$$

\section{TGase-directed putrescine incorporation}

The substrate capacity of $\beta_{\mathrm{L}}$-crystallin for TGase was tested after irradiation by determining the TGase-directed $\mathrm{Ca}^{2+}$. dependent incorporation of $\left[{ }^{14} \mathrm{C}\right]$ putrescine into trichloroacetic acid-insoluble material. The assay reaction mixture $(0.2 \mathrm{ml})$ contained $0.1 \mathrm{mg}$ of $\beta_{\mathrm{L}}$-crystallin, $5 \mathrm{mM}-\mathrm{CaCl}_{2}, 0.01$ unit of TGase and $50 \mathrm{~mm}$-Tris/ $\mathrm{HCl}, \mathrm{pH}$ 7.5. $\left[{ }^{14} \mathrm{C}\right] \mathrm{Putrescine}$ was added to a final concentration of $1 \mathrm{~mm}(0.5 \mu \mathrm{Ci})$. After $30 \mathrm{~min}$ of incubation at $37^{\circ} \mathrm{C}$ the reaction was stopped with $10 \%$ trichloroacetic acid $(1 \mathrm{ml})$. The precipitates, collected on Sartorius $25 \mathrm{~S}$ glass-fibre filters, were washed with $5 \%$ trichloroacetic acid, dried, and transferred into scintillation vials. The precipitates were dissolved in $1 \mathrm{ml}$ of Protosol solubilizer and scintillation solution was added $(7 \mathrm{ml})$. Radioactivity was determined with a liquid-scintillation counter.

\section{Protein fragmentation}

SDS/PAGE was performed with the discontinuous buffer system of Laemmli (1970) with a Protean slab-gel apparatus (Bio-Rad). A stacking gel of $2.5 \%(\mathrm{w} / \mathrm{v})$ acrylamide, a resolving gel of $15 \%$ acrylamide and a running buffer of $25 \mathrm{~mm}$-Tris/ $\mathrm{HCl} / 0.19 \mathrm{M}$-glycine $/ 0.1 \%$ SDS were employed, and $2.5 \mu \mathrm{g}$ of protein sample was applied per lane. Gels were stained with Coomassie Brilliant Blue and were calibrated with Boehringer molecular-mass standards of trypsin inhibitor $(20.1 \mathrm{kDa})$, lactate dehydrogenase $(36.5 \mathrm{kDa})$, glutamate dehydrogenase $(55.4 \mathrm{kDa})$ and phosphorylase $b(97.4 \mathrm{kDa})$.

\section{Tryptophan oxidation and thiol determination}

Tryptophan oxidation was measured as loss of $\beta_{\mathrm{L}}$-crystallin fluorescence peaks at $290 \mathrm{~nm}$ excitation and $350 \mathrm{~nm}$ emission after irradiation compared with unirradiated controls.

The measurement of thiol content was performed with Ellman's reagent [5,5'-dithiobis-(2-nitrobenzoic acid), $\mathrm{Nbs}_{2}$ ] by the method of Di Simplicio (1983). The samples containing irradiated crystallin were assayed at final concentration of $0.1 \mathrm{mg} / \mathrm{ml}$ in $0.1 \mathrm{M}$-phosphate buffer, $\mathrm{pH} 7.5(1.1 \mathrm{ml})$. The reaction was started by the addition of $50 \mu \mathrm{l}$ of $20 \mathrm{mM}_{-\mathrm{Nbs}_{2}}$, and the absorbance at $412 \mathrm{~nm}$ was measured 20 min later.

\section{RESULTS}

\section{Effect of the hydroxyl radical}

The effect of the hydroxyl radical was determined by using irradiation of solutions saturated with either $\mathrm{N}_{2} \mathrm{O}$ or with $\mathrm{N}_{2} \mathrm{O} / \mathrm{O}_{2}$ $(4: 1, v / v)$. Under all these conditions a biphasic response was seen: an increase in putrescine-incorporation capacity that was concentration-dependent up to $135 \mu \mathrm{M}$ free radicals, followed by a decrease in the value of this parameter at higher radical concentrations (Fig. 1). The maximum increase in putrescine incorporation was seen between 54 and $135 \mu \mathrm{M}-\mathrm{OH}^{\cdot}$ under these conditions. The maximum increase above control activity was around $57 \%$, regardless of the presence or absence of $\mathrm{O}_{2}$. The presence of $\mathrm{O}_{2}$ seemed to play a more marked role at higher $\mathrm{OH}^{\cdot}$ concentrations: at $540 \mu \mathrm{M}-\mathrm{OH}^{*}$ the amount of putrescine incorporation returned to control levels in samples irradiated in the absence of $\mathrm{O}_{2}$, but declined to $40 \%$ below control levels in the presence of $\mathrm{O}_{2}$.

\section{Effect of superoxide and hydroperoxyl radicals}

In contrast with the effect of $\mathrm{OH}^{*}$, it was found that the superoxide radical, $\mathrm{O}_{2}^{-}$, was completely ineffective in changing the substrate capacity of $\beta$-crystallin at similar radical concentrations (Fig. 2). We also examined the effect of the more reactive protonated form of this radical, $\mathrm{HO}_{2}{ }^{\circ}$ (Fig. 2). Again, this radical was largely ineffective until high concentrations were generated, but at $540 \mu \mathrm{M}-\mathrm{HO}_{2} \cdot$ the increase $(45 \%)$ in putrescine incorporation capacity was marked.

\section{Effect of organic peroxyl radicals}

Two organic peroxyl radicals species were tested for their effects on $\beta_{\mathrm{L}}$-crystallin: the thymine peroxyl radical and the acetone peroxyl radical (Fig. 3). With both of these radical species we found a pattern of effect similar to that found with $\mathrm{OH}^{\cdot}$. A biphasic response was again seen, with maximum increases in putrescine incorporation reaching similar levels to those induced by $\mathrm{OH}^{*}$ attack and occurring at similar radical concentrations. However, the decline in putrescine incorporation at higher radical concentrations was not so marked as with $\mathrm{OH}^{*}$. Thus, at peroxyl radical concentrations of about $300 \mu \mathrm{M}$, incorporation was still $30-40 \%$ above control levels whereas, with similar concentrations of $\mathrm{OH}^{*}$, putrescine incorporation was no longer above control levels.

\section{Protein fragmentation}

Analysis by SDS/PAGE of $\beta_{\mathrm{L}}$-crystallin after exposure to the various free radicals under study enabled us to compare the effects of the radicals on putrescine incorporation with their effects on $\beta_{\mathrm{L}}$-crystallin fragmentation. The $\mathrm{OH}^{\cdot}$ radical was found to be the most damaging, with extensive loss of the $\beta_{\mathrm{L}^{-}}$ crystallin subunit occurring at radical concentrations above $270 \mu \mathrm{M}$. The thymine and peroxyl free radicals also caused major 


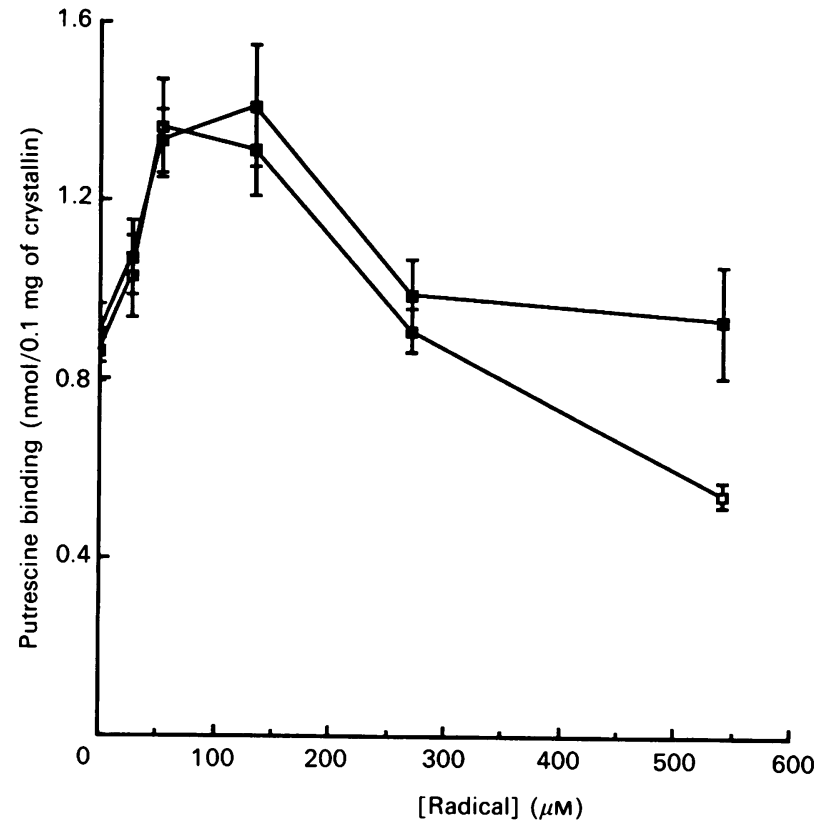

Fig. 1. Effect of $\mathrm{OH}^{\cdot}$ radicals on putrescine-incorporation capacity of $\beta$-crystallin

Solutions of crystallin $(1 \mathrm{mg} / \mathrm{ml})$ were irradiated under conditions generating hydroxyl radicals in the presence $(\square)$ or the absence $(\square)$ of $\mathrm{O}_{2}$. After irradiation, aliquots of crystallin were incubated with transglutaminase and $\left[{ }^{14} \mathrm{C}\right]$ putrescine and the extent of putrescine incorporation was measured. Full details are given in the Materials and methods section.

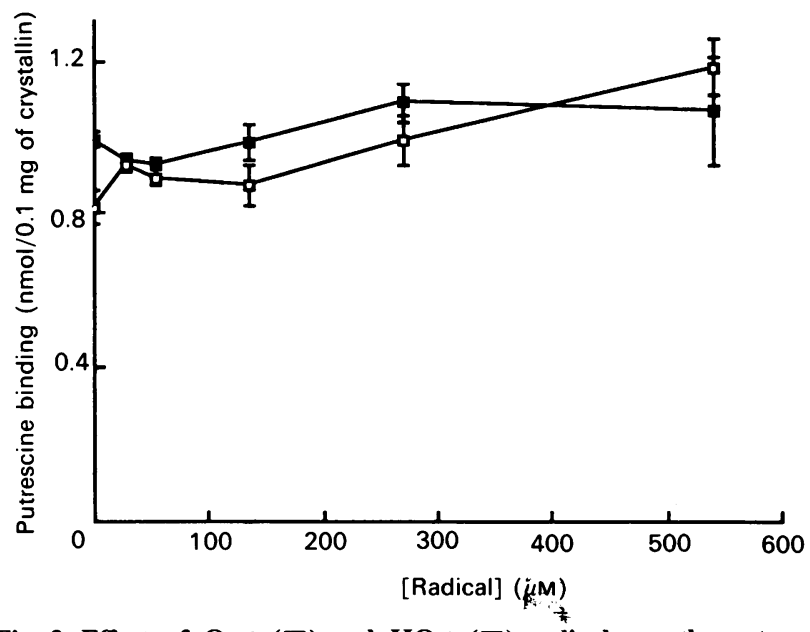

Fig. 2. Effect of $\mathrm{O}_{2}^{-\cdot}(\square)$ and $\mathrm{HO}_{2}{ }^{-}(\square)$ radicals on the putrescineincorporation capacity of $\boldsymbol{\beta}$-crystallin

The procedure was as indicated in the legend to Fig. 1, except for the specific irradiation conditions (see the Materials and methods section).

fragmentation of the $\beta_{\mathrm{L}}$-crystallin at radical concentrations above $260 \mu \mathrm{M}$. In contrast, the $\mathrm{O}_{2}^{-\cdot}$ and $\mathrm{HO}_{2}{ }^{-}$radicals produced no detectable fragmentation, even at the highest concentrations. These data are summarized in Fig. 4, where, for reasons of space, only the results using 0,135 and $540 \mu \mathrm{M}$ concentrations of the radicals $\mathrm{OH}^{\cdot}, \mathrm{O}_{2}{ }^{-\cdot}, \mathrm{HO}_{2}{ }^{-}$and thymine peroxyl are shown. None of the fragments were sufficiently large to be retained by the gel, and no radical-induced polymerization products were evident.

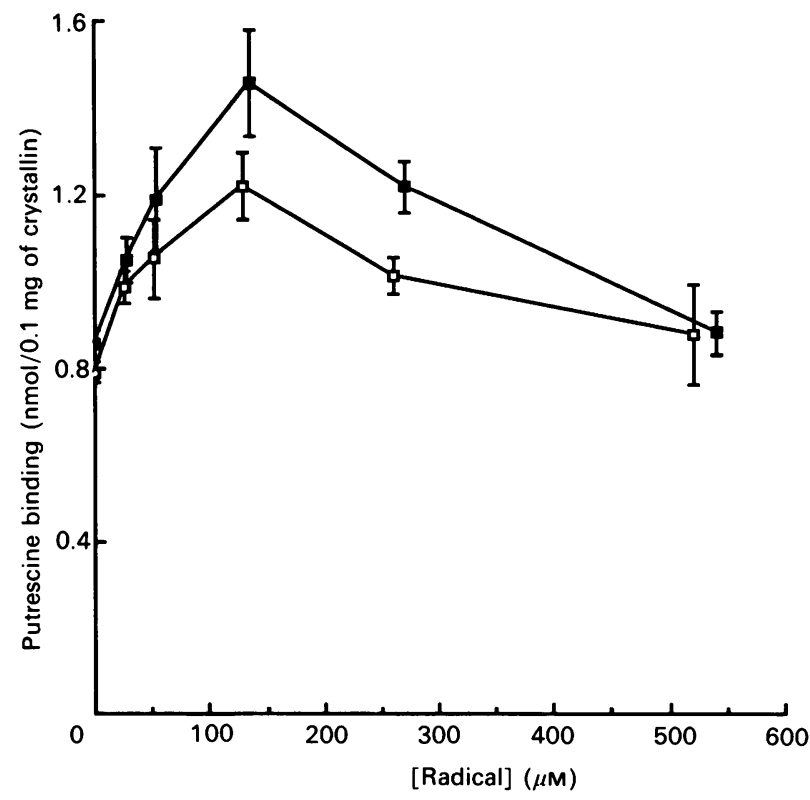

Fig. 3. Effect of thymine peroxyl radicals $(\square)$ and acetone peroxyl radicals $(\square)$ on the putrescine-incorporation capacity of $\boldsymbol{\beta}$-crystallin

The procedure as indicated in legend to Fig. 1, except for the specific irradiation conditions.

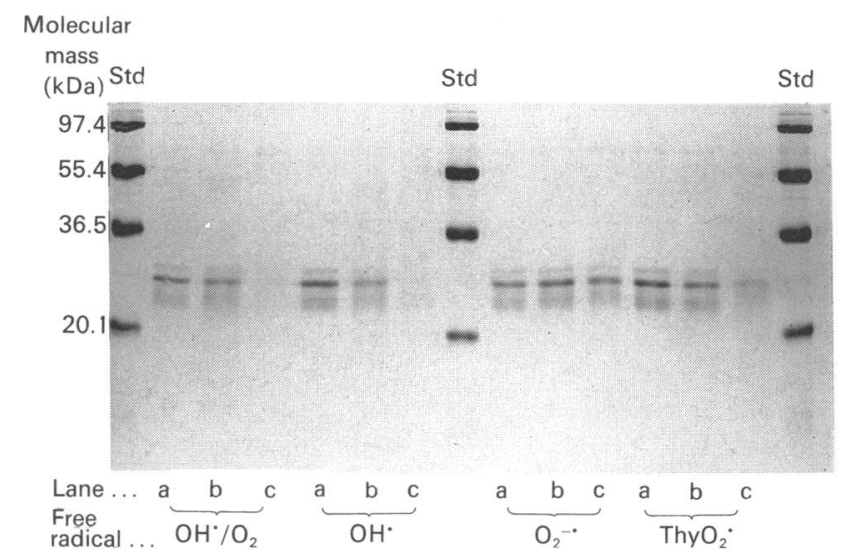

Fig. 4. SDS/PAGE of $\beta_{\mathrm{L}}$-crystallin before and after exposure to free radicals

The protein was exposed to $\mathrm{OH}^{\bullet}$ (in the presence and absence of $\mathrm{O}_{2}$ ), $\mathrm{O}_{2}{ }^{-\cdot}$ or thymine peroxyl radical $\left(\mathrm{ThyO}_{2}{ }^{-}\right)$at a range of radical concentrations. For reasons of space only the results of exposure to 0 (lane a), 135 (lane b) and 270 (lane c) $\mu \mathrm{M}$-radical are shown. Abbreviation: Std, standards of indicated molecular mass.

\section{Protein thiol content and tryptophan fluorescence}

The effects of the various radical species on the thiol concentration of $\beta_{\mathrm{L}}$-crystallin and on its intrinsic tryptophandependent fluorescence were also monitored. In summary, $\mathrm{OH}$ and the thymine and acetone peroxyl free radicals were very active in terms of oxidizing the thiol groups in a concentrationdependent manner, whereas the $\mathrm{O}_{2}^{-\cdot}$ and $\mathrm{HO}_{2}{ }^{-}$radicals were without effect, except at the highest concentrations. Similarly, tryptophan fluorescence was strongly decreased by the $\mathrm{OH}^{\cdot}$ and organic peroxyl radicals in a concentration-dependent manner, whereas the $\mathrm{O}_{2}^{--}$and $\mathrm{HO}_{2}^{-}$were again ineffective at all concentrations. These data are summarized in Tables 1 and 2. 
Table 1. Effect of various free radicals on crystallin thiol concentration

Crystallin was exposed to free radicals and its thiol content measured as described in the text. Results are means \pm S.E.M. from three independent experiments. Abbreviations: $\mathrm{ThyO}_{2}{ }^{\circ}$, thymine peroxyl radical; $\mathrm{AceO}_{2}{ }^{\circ}$, acetone peroxyl radical. Statistical significance (Student's $t$ test; relative to unirradiated control): ${ }^{\mathrm{a}} P<0.001 ;{ }^{\mathrm{b}} P<0.01 ;{ }^{\mathrm{c}} P<0.05$; no symbol, not significantly different.

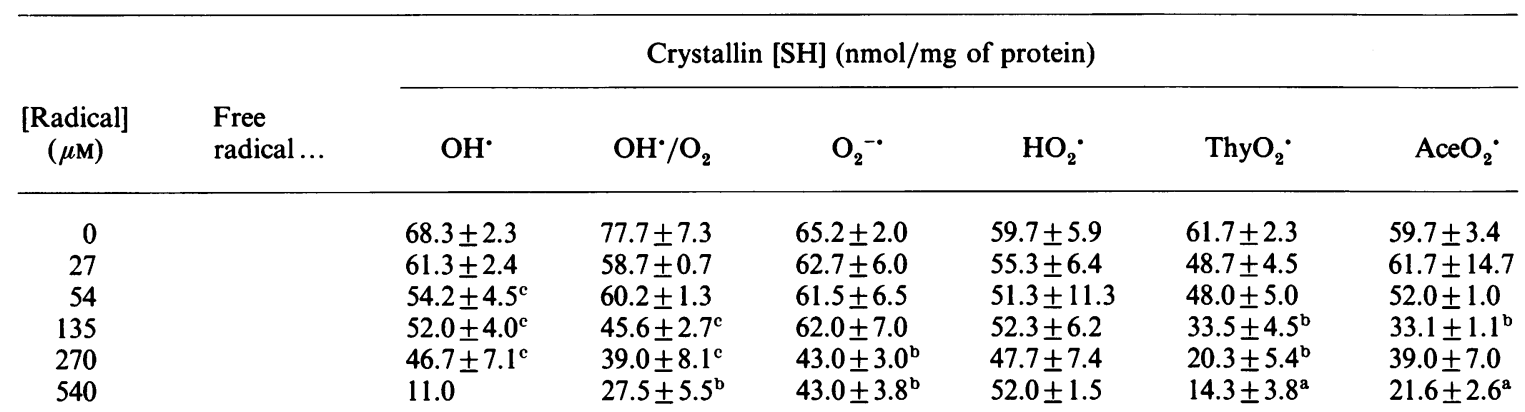

Table 2. Effect of various free radicals on crystallin tryptophan fluorescence

Crystallin was exposed to free radicals and tryptophan fluorescence was determined as described in the text. Data are means \pm S.E.M. from three independent experiments. Abbreviations and statistical significances are as in Table 1.

Tryptophan fluorescence (arbitrary units)

\begin{tabular}{|c|c|c|c|c|c|c|c|}
\hline $\begin{array}{c}\text { [Radical] } \\
(\mu \mathrm{M})\end{array}$ & $\begin{array}{l}\text { Free } \\
\text { radical ... }\end{array}$ & $\mathrm{OH}^{\cdot}$ & $\mathrm{OH}^{*} / \mathrm{O}_{2}$ & $\mathrm{O}_{2}^{-\cdot}$ & $\mathrm{HO}_{2}{ }^{-}$ & $\mathrm{ThyO}_{2}{ }^{-}$ & $\mathrm{AceO}_{2}{ }^{\circ}$ \\
\hline $\begin{array}{r}0 \\
27 \\
54 \\
135 \\
270 \\
540\end{array}$ & & $\begin{array}{c}165 \pm 10 \\
142 \pm 7 \\
145 \pm 9 \\
123 \pm 6^{b} \\
93 \pm 7^{\mathrm{a}} \\
57 \pm 7^{\mathrm{a}}\end{array}$ & $\begin{array}{r}161 \pm 3 \\
139 \pm 2^{\mathrm{a}} \\
139 \pm 1^{\mathrm{a}} \\
108 \pm 1^{\mathrm{a}} \\
84 \pm 3^{\mathrm{a}} \\
29 \pm 4^{\mathrm{a}}\end{array}$ & $\begin{array}{l}161 \pm 2 \\
164 \pm 5 \\
152 \pm 4 \\
159 \pm 1 \\
162 \pm 4 \\
159 \pm 2\end{array}$ & $\begin{array}{l}142 \pm 3 \\
157 \pm 9 \\
147 \pm 5 \\
137 \pm 11 \\
149 \pm 4 \\
145 \pm 1\end{array}$ & $\begin{array}{c}127 \pm 6 \\
109 \pm 6 \\
99 \pm 6^{\mathrm{b}} \\
87 \pm 5^{\mathrm{a}} \\
59 \pm 1^{\mathrm{a}} \\
39 \pm 2^{\mathrm{a}}\end{array}$ & $\begin{array}{c}121 \pm 2 \\
102 \pm 5^{\mathrm{b}} \\
103 \pm 9 \\
74 \pm 4^{\mathrm{a}} \\
58 \pm 3^{\mathrm{a}} \\
42 \pm 5^{\mathrm{a}}\end{array}$ \\
\hline
\end{tabular}

\section{DISCUSSION}

The lens proteins afford unique advantages for the study of age-related changes, owing to their extremely slow turnover. The changes in lens crystallins that have been most intensively studied are those produced by oxidation due to the production of reactive oxygen species (see Taylor \& Davies, 1987) and those produced by transglutaminase activity (Lorand et al., 1985; Velasco \& Lorand, 1987; Zigler et al., 1989). Previously these have been considered as independent phenomena, but we propose that they are related, in that exposure of crystallins to oxidants may predispose them to enhanced transglutaminase activity, leading to the formation of cross-links. Our preliminary data in support of this hypothesis came from studies in which $\beta_{L^{-}}$ crystallin was exposed to a glucose/glucose oxidase mixture that generates $\mathrm{H}_{2} \mathrm{O}_{2}$ and may indirectly yield oxygen free radicals (Brossa et al., 1990). $\beta_{\mathrm{L}}$-Crystallin susceptibility to TGase activity was increased by over $100 \%$, but it was not clear from those experiments which oxidizing species was responsible for this effect. The results presented here confirm this original observation that oxidative reactions enhance the susceptibility of $\beta_{\mathrm{L}}$-crystallin to TGase activity. It is clear, however, that $\mathrm{O}_{2}^{-\cdot}$ is incapable of modifying $\beta_{\mathrm{L}}$-crystallin so as to increase its susceptibility to TGase, and even its more reactive protonated form $\left(\mathrm{HO}_{2}^{\circ}\right)$ only shows such activity towards $\beta_{\mathrm{L}}$-crystallin at the highest concentration studied here. Although $\mathrm{O}_{2}^{-\cdot}$ is probably the most commonly produced oxygen free radical in animal cells, it is generally held that it is not a particularly damaging species in itself, owing to its relatively low chemical reactivity. The lack of effect on crystallin thiol groups, tryptophan fluorescence and polypeptide fragmentation, used here as general markers of protein damage for comparison, support this. The significance of $\mathrm{O}_{2}^{-\cdot}$ production in cells lies more in its potential as a precursor for $\mathrm{OH}^{\cdot}$ production, the latter being a far more reactive oxidizing species. Here we demonstrate that the $\mathrm{OH}^{\cdot}$ radical is by itself capable of modifying $\beta_{\mathrm{L}}$-crystallin so as to enhance its capacity as a TGase substrate. Simultaneously, at all concentrations studied, $\mathrm{OH}^{\cdot}$ damages $\beta_{\mathrm{L}}$-crystallin in terms of thiol oxidation and loss of tryptophan fluorescence. Fragmentation of the polypeptide chain was difficult to quantify, and the degree of fragmentation at low $\mathrm{OH}^{-}$concentrations cannot be estimated. The biphasic response curve for putrescine incorporation suggests that a limited amount of protein modification enhances TGase substrate capacity, but that higher concentrations of $\mathrm{OH}^{*}$ fragment the protein so much as to begin to destroy its capacity to act as a substrate. The same argument also applies to the organic peroxyl free radicals studied. Organic peroxyl radicals are less reactive in general than $\mathrm{OH}^{*}$, but may be more damaging by being more selective in their targets, and they are increasingly implicated as important damaging species (Willson, 1985). In the present study, thymine peroxyl and acetone peroxyl radicals showed an activity profile very similar to that of $\mathrm{OH}^{\circ}$, with the exception that, at the higher concentrations, the peroxyl radicals still enhance putrescine-incorporation capacity, possibly indicating that they are less destructive. By way of comparison, Wolff \& Dean (1986) found thymine peroxyl radicals incapable of fragmenting albumin, whereas Gee et al. (1985) found this radical capable of inactivating alcohol dehydrogenase. These are important observations, since it is more likely that organic peroxyl radicals, with their longer half-lives, will be the ultimate 
damaging species in the cell rather than $\mathrm{OH}^{*}$, which is so reactive as to be limited to reacting with whatever biomolecule is present at its site of production (Slater, 1976).

The effect of the presence of $\mathrm{O}_{2}$ seems to be to promote the damaging effects of $\mathrm{OH}^{*}$, tipping the balance from enhanced TGase susceptibility to excessive destruction of the polypeptide chain, probably as a consequence of the formation of peroxyl radicals on the protein itself. In general terms, these data are in agreement with recent reports by other workers (Dean et al., 1986; Wolff \& Dean, 1986; Wolff et al., 1986; Davies, 1987) who, in studies of radical attack on other proteins, conclude that $\mathrm{OH}^{\cdot}$ is readily capable of fragmenting polypeptide chains, whereas $\mathrm{O}_{2}^{-\cdot}$ is not.

In conclusion, the present study has confirmed our hypothesis that the action of reactive oxygen species upon $\beta_{\mathrm{L}}$-crystallin increases the susceptibility of this protein to TGase activity. Further, it identifies which free radicals are likely to be responsible for this effect and which are not. Further work will be directed towards fully understanding the mechanism of this effect, which probably depends on changes in the conformation of the protein so as to expose more glutamine residues. This study not only reinforces the theory that oxidizing free radicals are important in pathological changes to crystallins, but also enables us to consider TGase-dependent changes as a related phenomenon rather than a separate one.

We are very grateful to Professor Robin Willson and Dr. Tony Garner for valuable discussions.

\section{REFERENCES}

Anderson, E. I. \& Spector, A. (1978) Exp. Eye Res. 26, 407-417

Brossa, O., Seccia, M. \& Gravela, E. (1990) Free Radical Res. Commun., in the press

Clark, J. I., Mengel, L., Bagg, A. \& Benedek, G. B. (1980) Exp. Eye Res. 31, 399-410

Davies, K. J. A. (1987) J. Biol. Chem. 262, 9895-9901

Dean, R. T., Thomas, S. M. \& Garner, A. (1986) Biochem. J. 240, 489-494

Received 16 July 1990/15 October 1990; accepted 26 October 1990
Di Simplicio, P. (1983) Pharmacol. Res. Commun. 15, 805-814

Duncan, G. \& Bushell, A. R. (1975) Exp. Eye Res. 20, 223-230

Fricke, H. \& Hart, E. J. (1966) Radiation Dosimetry (Attix, F. H. \& Roesch, W. C., eds.), Academic Press, New York

Gee, C. A., Kitteridge, K. J. \& Willson, R. L. (1985) Br. J. Radiol. 58, 251-256

Harding, J. J. (1972) Biochem. J. 129, 97-100

Harding, J. J. (1981) in Molecular and Cellular Biology of the Eye Lens (Bloemendal, H., ed.), pp. 327-366, John Wiley, New York

Jedziniak, K. A., Kinoshinita, J. H., Yates, E. M., Hocker, L. O. \& Benedek, G. B. (1972) Invest. Ophthalmol. 11, 905

Kramps, H. A., Hoenders, H. J. \& Wollensak, J. (1976) Biochim. Biophys. Acta 434, 32-43

Kramps, H. A., Hoenders, H. J. \& Wollensak, J. (1978) Exp. Eye Res. 27, 731-735

Krause, A. C. (1934) The Biochemistry of the Eye, The Johns Hopkins Press, Baltimore

Laemmli, U. K. (1970) Nature (London) 227, 680-685

Lorand, L., Hsu, L. K. H., Siefring, G. E., Jr. \& Rafferty, N. S. (1981) Proc. Natl. Acad. Sci. U.S.A. 78, 1356-1360

Lorand, L., Conrad, S. M. \& Velasco, P. T. (1985) Biochemistry 24, $1525-1531$

Slater, T. F. (1976) in Recent Advances in Biochemical Pathology: Liver Injury (Dianzani, M. U., Ugazio, G. \& Sena, L. M., eds.), pp. 381-390, Minerva Medica, Turin

Spector, A. (1985) in The Ocular Lens (Maisel, H., ed.), pp. 405-438, Marcel Dekker, New York

Taylor, A. \& Davies, K. J. A. (1987) Free Radicals Biol. Med. 3, 371-377

Truscott, R. J. W. \& Augustein, R. C. (1977a) Exp. Eye Res. 25, 139-148

Truscott, R. J. W. \& Augustein, R. C. $(1977 b)$ Biochim. Biophys. Acta 492, 43-52

Velasco, P. T. \& Lorand, L. (1987) Biochemistry 26, 4629-4634

Willson, R. L. (1978) in Biochemical Mechanisms of Liver Injury (Slater, T. F., ed.), pp. 123-224, Academic Press, London

Willson, R. L. (1985) in Oxidative Stress (Sies, H., ed.), pp. 41-72, Academic Press, London

Wolff, S. P. \& Dean, R. T. (1986) Biochem. J. 234, 399-403

Wolff, S. P., Garner, A. \& Dean, R. T. (1986) Trends Biochem. Sci. 11 $27-31$

Zegota, H., Schuchmann, M. N., Schulz, D. \& von Sonntag, C. (1986) Z. Naturforsch. 41b, 1015-1022

Zigler, S. J., Jr. \& Goosey, J. (1981) Trends Biochem. Sci. 6, 133-136

Zigler, S. J., Jr., Huang, Q. L. \& Du, X.-Y. (1989) Free Radicals Biol. Med. 7, 499-505 